\title{
Make a difference: Connect, contribute, collaborate
}

\section{Volunteer for division and section committees and editorial boards}

A re you looking for ways to expand your professional network and contribute to ACRL? Committee volunteers help shape ACRL by advancing its strategic plan and influencing the direction of academic and research librarianship. Serving on a committee or editorial board is a great way to become involved and make an impact on the profession.

If you'd like to become more engaged, ACRL Vice-President/President-Elect Jon E. Cawthorne invites you to volunteer to serve on a 2020-21 division or section committee.

Thank you for volunteering to contribute your time and expertise to ACRL! Our association relies on the time, energy, and talent of our member volunteers to carry out the work of the association. In the interests of creating an appointment process that is as transparent as possible, I will issue a statement informing the membership of the number of opportunities and volunteers, and other relevant information, after the appointments process is complete. Thank you.-Jon E. Cawthorne, ACRL vice-president/ president-elect

\section{The rewards of volunteering}

Volunteering offers many benefits and opportunities. You can:
- connect with others in the profession who are passionate and committed to academic librarianship,

- learn from those who share similar professional concerns and interests,

- network with information professionals in higher education,

- become part of a community of academic and research librarians,

- gain insights into the profession,

- enhance your leadership skills through group facilitation and project management,

- discover new ways to work,

- expand your awareness and understanding of the value of academic libraries in higher education,

- influence and advance the work of the association and the profession, and

- promote excellence within the profession.

\section{The appointment process}

Appointments are made at the division and section level, and through the editorial board process (see editorial board section). Section vice-chairs are responsible for committee appointments for the year they will serve as chair. The ACRL vicepresident is responsible for committee appointments at the division level for the year he or she serves as president. The ACRL Appointments Committee assists the vice-president in an advisory capacity. Division-level committees are created 
to conduct the work of the Board of Directors, and each committee crafts an annual work plan in consultation with their Board and staff liaisons to accomplish the charged activities and responsibilities.

Current committee members whose terms conclude at the 2020 ALA Annual Conference should submit a new volunteer form if they wish to be considered for reappointment. The online volunteer form closes February 14 , and most committee appointment offers will be sent in April and May 2020.

Members of all ACRL committees, task forces, and similar bodies are expected to fully participate in the work of the group, whether it be working virtually or face-toface. However, much work can be done virtually and onsite attendance at the ALA Midwinter Meeting and the ALA Annual Conference is not a requirement of committee service.

\section{Factors influencing appointment}

Although the appointment process may reflect the priorities of the vice-president/ president-elect and section vice-chairs, several factors are always considered:

- Evidence of interest and expertise. Have prospective volunteers visited and/ or posted to the committee's ALA Connect community, introduced themselves to the chair, or attended the meetings (virtual or face-to-face)? Do they have knowledge and/ or previous experience that relates to the work of the committee? Have they indicated their interest on the volunteer form?

- Demographics and composition of committee. A balance is sought with respect to type of library (community college, college, or university), geographic representation, ethnic diversity, and gender. Those who have not had the opportunity to serve on an ACRL committee are encouraged to volunteer, as it is important to add new perspectives.

- Recommendation of the current committee chair. Current committee chairs are asked to suggest prospective members.

- Willingness to participate in the work of the committee. Volunteers should be prepared to engage in the committee work year-round.

The final appointments are the prerogative of the ACRL president-elect and the section vice-chairs.

\section{How to apply}

1. Identify the committees that interest you. ACRL committees and their charges are listed on the ACRL Directory of Leadership (www.ala.org/acrl/aboutacrl/directoryofleadership/committees). Check out the committee's space in ALA Connect, where documents, discourses, and the work of the committees are posted. Attend face-to-face (or virtual) committee meetings at the Midwinter Meeting and Annual Conference to decide if their activities interest you. Talk/ email with committee members. Express your interest to the committee chair. Ask about current projects, and explain how you might contribute to the work of the committee.

2. Submit a volunteer form (Internet Explorer is the preferred browser for accessing the form). Volunteer forms should be submitted by February 14, 2020. You will be asked to log in using your ALA member ID and the password you created. Be sure that you are a current ALA/ACRL member before attempting to login.

To volunteer for a division-level or section committee, complete the online volunteer form at www.ala.org/CFApps/volunteer /form.cfm.

If you experience issues logging into the form, please contact ALA Member and Customer Service at (800) 545-2433, ext. 5, to check your membership status.

3. Volunteer again and check out other opportunities. If you are not appointed, volunteer again next year. In addition, continue to explore ACRL's many opportunities to network and connect at www.ala.org /acrl/aboutacrl/getinvolved/. Review the many discussion and interest groups. Each group selects a new leader in the spring outside of the volunteer process described 
above. If you'd like to start a new discussion or interest group, contact Lauren Carlton at lcarlton@ala.org.

\section{ACRL division-level committee appointments}

ACRL committees (and their charges) can be found on the ACRL website (www.acrl. org, select "Directory of Leadership" from the menu bar).

Appointments to ACRL standing committees are made in the spring for terms beginning immediately after the ALA Annual Conference. The Appointments Committee sends appointment recommendations to the ACRL president-elect. The president-elect makes the final appointments for the committees.

Questions about division-level appointments may be directed to the Appointments Committee Chair Meghan Elizabeth Sitar, director of Connected Scholarship, University of Michigan, msitar@umich.edu.

If you have any questions about using the volunteer form, please contact ACRL Program Manager for Strategic Initiatives Allison Payne for division committees at apayne@ala.org or (312) 280-2519 or ACRL Senior Program Officer Megan Griffin for section committees at mgriffin@ala.org or (312) 280-2514.

\section{ACRL section appointments}

ACRL sections help members customize their ACRL experience through newsletters, electronic discussion lists, specialized programming, preconferences, recognition, and various initiatives. To learn more, visit www. ala.org/acrl/aboutacrl/directoryofleadership /sections.

Section vice-chairs appoint members to section committees. Most appointments are made in the spring for terms beginning immediately after the ALA Annual Conference.

If you wish to be considered for a section committee appointment, complete the ACRL volunteer form at www.ala.org/CFApps /volunteer/form.cfm by February 14, 2020. (Internet Explorer is the preferred browser for accessing the form.) For more information about section appointments, please contact section vice-chairs:

Anthropology and Sociology Section. Juliann Couture, University of Colorado Boulder, email: juliann.couture@colorado.edu.

Arts Section. Mackenzie Salisbury, School of the Art Institute of Chicago, email: ssalis1@artic.edu.

College Libraries Section. Mary Mallery, Brooklyn College-CUNY, email: mary. mallery@brooklyn.cuny.edu.

\section{Community and Junior College Librar-} ies Section. Martin House, Central Piedmont Community College, email: martin.house@ cpcc.edu.

Digital Scholarship Section. Kristen Totleben, University of Rochester, email: ktotleben@gmail.com.

Distance Learning Section. Amanda Ziegler, Northcentral University, email: amanda.ziegler@gmail.com.

\section{Education and Behavioral Sciences} Section. April Hines, University of Florida, email: aprhine@ufl.edu.

European Studies Section. Thomas Keenan, Princeton University, email: tkeenan@princeton.edu.

Instruction Section. Nikhat Ghouse, American University, email: ghouse @american.edu.

Literatures in English Section. Brian Flota, James Madison University, email: flotabc@jmu.edu.

Politics, Policy and International Relations Section. Erin Ackerman, The College of New Jersey, email: ackermae@tcnj.edu.

Rare Books and Manuscripts Section. 
Petrina Jackson, Syracuse University, email: pdjackso@syr.edu.

Science and Technology Section. Rachel Borchardt, American University, email: borchard@american.edu.

University Libraries Section. Michelle Demeter, New York University, email: michelle.demeter@nyu.edu.

Women and Gender Studies Section. Sharon Ladenson, Michigan State University, email: ladenson@msu.edu.

\section{Editorial boards}

ACRL has ten editorial/advisory boards for its publications: ACRL/LLAMA Interdivisional Academic Library Facilities Survey Editorial Board; Academic Library Trends and Statistics Survey Editorial Board; CHOICE Editorial Board; College \& Research Libraries Editorial Board; College $\mathcal{E}$ Research Libraries News Editorial Board; New Publications Advisory Board; Project Outcome for Academic Libraries Editorial Board; Publications in Librarianship Editorial Board; RBM: A Journal of Rare Books, Manuscripts, and Cultural Heritage Editorial Board; and Resources for College Libraries Editorial Board.

Appointments to editorial boards are made after the ALA Midwinter Meeting for terms that begin immediately after the ALA Annual Conference. The editors recommend the names of individuals to fill vacancies. The Publications Coordinating Committee approves the recommendation and the ACRL vice-president /president-elect makes the appointment.

If you would like to be considered for appointment to an editorial board, contact the editor of the editorial board early in the fall, and indicate your interest on the ACRL online volunteer form.

Academic Library Trends and Statistics Survey Editorial Board chair: Adrian K. Ho, University of Kentucky; phone: (859)
218-0895; email: hoadriank@gmail.com.

ACRL/LLAMA Interdivisional Academic Library Facilities Survey Editorial Board ACRL co-chair: Anne Marie Casey, Embry-Riddle Aeronautical University; phone: (386) 226-6593; email: caseya3@ erau.edu.

CHOICE Editorial Board editor: Mark Cummings, Choice; phone: (800) 347-6933 x29; email: mcummings@ala.org.

College \& Research Libraries Editorial Board editor: Wendi Arant Kaspar, Texas A\&M, phone: (979) 862-6310; email: warant@tamu.edu.

College \& Research Libraries News Editorial Board editor: David Free, ACRL; phone: (312) 280-2517; email: dfree@ala.org.

New Publications Advisory Board chair: Courtney Greene McDonald, University of Colorado-Boulder; phone: (303) 735-8638; email: crmcdonald@colorado. edu.

Project Outcome for Academic Libraries Editorial Board chair: Tiffany Garrett, Nevada State College; phone: (702) 9922807; email: tiffany.garrett@nsc.edu.

Publications in Librarianship chair: Daniel Mack, University of Maryland Libraries; phone: (301) 405-9264; email: dmack@ umd.edu.

RBM: AJournal of Rare Books, Manuscripts, and Cultural Heritage editor: Richard Saunders, Southern Utah University; phone: (435) 865-7947; email: rsaunders@ suu.edu

Resources for College Libraries chair: Tammera Race, New College of Florida; phone: (941) 487-4405; email: trace@ncf. edu. 2 